\title{
DOES INSTITUTIONAL QUALITY INCREASE FRAGILITIES IN AFRICA? A RECENT ANALYSIS
}

\author{
Richard ZOGO EKASSI ${ }^{1}$, Bruno Emmanuel ONGO NKOA²and Jacques Simon SONG ${ }^{3}$ \\ ${ }^{1}$ University of Yaounde II, Cameroon \\ ${ }^{2}$ Corresponding author, University of Dschang, Cameroon \\ ${ }^{3}$ University of Dschang, Cameroon
}

DOI: 10.46609/IJSSER.2021.v06i07.034 URL: https://doi.org/10.46609/IJSSER.2021.v06i07.034

\begin{abstract}
In this article, we appreciate the effects of institutional quality on five dimensions of fragilitiesin Africa: economic, political, social, security and environmental. From a sample of 51 countries, we estimate a model in panel data by the Two Stage Least Square (2SLS), so robustness is tested by a Probit model over the period 1995-2016. Our results show that, Corruption, Rule of Law and Regulation quality increase global, economic, political, social, security and environmental fragilities in Africa. We then suggest the strengthening of institutional quality through the implementation of a people-based democratic system where the leadership commitment is a priority.
\end{abstract}

Keywords: Africa, Fragilities, Institutions, 2SLS.

JEL Classifications: D63, F22, F24, F35, R21.

\section{Introduction}

The concept of fragility is fundamentally linked to institutions. It stems from the modification of uses, rules and regulations added to the growing interconnection of world economies. Fragility usually describes a combination of State dysfunctions such as the inability to supply basic social services, bad governance, persistence of poverty and a poor territory control (Bertocchi \& Guerzoni, 2012). Every country is experiencing or has experienced fragility situations. Keynes (1936) underscores that the occurrence of some events is uncertainand whatever is their degree of accuracy, they are out of the authorities' control. The stock market crash of 1929 displayed the American government weakness to forecast events. The same example shall be found in the work of Minsky (1992) and also enlightened by Sinapi et al., (2010). Hence, the financial fragility reflecting the indebtedness structure of balance sheet with a high financial and operational risks 


\section{International Journal of Social Science and Economic Research}

ISSN: $2455-8834$

Volume:06, Issue:07 "July 2021"

taking.

According to the OECD (2017, p.16), fragility is defined as «the combination of exposure to risk and insufficient coping capacity of the State, system and/or communities to manage, absorb or mitigate those risks ». By the end of the cold war, the concept of «fragile State » denoted countries facing hunger, war and poverty. Another interpretation is given to this expression in the aftermaths of the 9/11 attacks with terror going violent. The ADB report (2014, p.2) considers it as « condition of elevated risk of institutional breakdown, societal collapse or violent conflict ». Socioeconomic violence's add to violence leading to wars. The growing interest for fragile States has led to the definition of a fragility index. In the its report entitled Index of state weakness in the developing world (2008), the Brooking Institute defines a fragility index based on the poverty, security, management and conservation of natural resources. The French Development Agency and the World Bank have developed useful economic and environmental indicators. However, the OECD identifies five dimensions of fragility namely: economic, environmental, political, societal and security.

From 2016 to 2018, the number of people living in a fragility context in the world movedfrom 1.6 billion to 1.8 billion. Nearly 200 million people lived under a fragility situation. If the situation remains unchanged, 2.3 billion people will be living in fragile States by 2025 (OCDE,2018). On 66 countries considered fragile or extremely fragile in the world in 2019, 47 are recorded in Africa, compared to 7 in East Asia and the Pacific, 6 in the Middle East, 3 in Latin America and the Caribbean, 2 in South Asia, and 1 in Europe (Fund for Peace, 2019). In 2015,43,786 people have been killed or wounded by explosive devices. The death toll pertaining to terror attacks increased by $63 \%$ in 2013 with more than 18.000 deceases. According the Fund For Peace, over a scale of 120 points, global fragility is deeper in Somalia (113), CAR (111), Democratic Republic of Congo (110), Sudan (108) and Chad (108). Although security policies have been implemented by governments, the roots of terrorism seem to deeper than what thinkthe ordinary public.

Besides the violence, fragility situations are fueled by the extreme poverty rocking people. The World Bank report (2016) underlines that around 836 million people live with lessthan US\$ 1.9 per day. Fortunately, forecasts are most optimistic indicating that the number of poor would decrease along the two upcoming decades. That is, the number of people living in extreme poverty would drop from 480 million in 2015 to 542 millions in 2035. The Economic Commission for Africa (ECA) underlines that more than one third of the 68 millions people compelled to move across the world are in Africa. The African Union (AU) declared the year 2019 as the « year of refugees, expatriates and displaced people: towards sustainable solutions to forced immigration in Africa ». 


\section{International Journal of Social Science and Economic Research}

ISSN: $2455-8834$

Volume:06, Issue:07 "July 2021"

However, the African countries counsel emphasizes on the quality of institutions that hampers countries' resilience capacity. Along the same vein, the World Bank (2014) highlightsthat all subSaharan countries experience fragility at various levels. This fragility is marked by institutional weaknesses that hinder countries from reducing social costs and uncertainties, their ability to generate a standard framework as well as the capacity to forecast social changes, to garanty citizens' security and to supply public good and services.

The institutional structure weighs doubly in the analysis of countries fragility, economic and financial systems. It allows the strengthening of inciting mechanisms by deepening fragility and/or fuels the dynamics of crises. On the other hand, it can contain incentives and reduce fragility. Lasida (2014) underlines that multiforms crises recorded by countries have endogenous causes. There are not conjectural nor epidermal but rather belong from institutions whose the nonobservance of regulations can lead to irreversible situations. According to the Country Policy and Institutional Assessment (CPIA), Rwanda (4) is the first African country having strong institutions and whose resilience index is estimated to 87. Botswana ranked among the ten first countries having an institutional performance is also the safest African country (16.9). However, Uganda ranked among the world 20 most fragile countries and among the 14 most fragile African countries has an institutional performance index of 3.7. Hence, it gives off a contrast between institutional quality and State fragility justifying the relevance of our study.

The literature on the determinants of States fragility regularly underscores the insufficiency of welfare (Judson and Orphanides, 1999). According Dunne and Tian (2019), armed conflicts weaken the economic resilience and fragilize countries. Boer (2015) underlines the important role of political instability, the persistence of corruption and the volatility of growth. At contrario, Macedo et al., (2018), from a study in Brazil showed that environmentalfragility is subsequent to the human action, natural disasters, rugged landscape and irregular precipitations due to climate changes. These non consensual results account for the diversity ofthe characteristics of the study areas as well as the fragilities indicators considered. Indeed, considering its complex and multidimensional nature, several measures have been suggested by international institutions out of which two look relevant: the first one is proposed by the FFP made up of five dimensions (Economic, political, societal, and environmental and security). The consideration of real factors allows to use a larger sample including African countries. Hence, a country shall be considered fragile if it indexes on a scale 0 to 120 is greater than 60 . The second is that put forward by the WB measured by the Country Policy and Institutional Assessment (CPIA), which considers as fragile any country figuring among the lowest $40 \%$ of the CPIA index on a list of 180 countries. (Fearon, 2011).

Notwithstanding the diversity of the measures used, the impact of the quality of institutions as a 


\section{International Journal of Social Science and Economic Research}

ISSN: $2455-8834$

Volume:06, Issue:07 "July 2021"

source of countries fragility remains less explored in Africa. Two reasons justify the interest for this study; a high number of registered fragile countries are in Africa andalso, Africa remains the continent experiencing the weakest institutions around the world. Baseon the aforementioned, the questioning over the existence of a robust relationship between thequality of institutions and the fragility remains up to date. Though it's yet to be empirically investigated, the OECD answers to this issue is affirmative.

Noticing their positive effects, institutions are the roots of multidimentional fragilities (Liu and Boqiang, 2019). The existing works are not unanimous and undermine the specificityof regions. The African continent has unfortunately paid very few attentions to the concept of fragility which is rather a willful act; that is, the strengthening of the institutional framework would reduce the pressure of international firms on States, the possession of lands illustrates the social fragility.

From the theorical framework and the empirical methodologies widely documented in the literature, the aim of this study is to analyze the effects of institutional quality over five dimensions of fragility in Africa. To this end, we considered a sample of 51 African countries over the period 1996-2016. We then applied the Two Stage Least Squares (2SLS) approach. The results show that the institutional quality increases the global fragility in Africa. This workbuilds the literature at least in three aspects. First of all, in addition to the traditional determinants considered (conflicts, wars, natural disasters, inflation), it fits in the quality of institutions as a relevant indicator of the State fragility. Then, it completes and empirically enriches the works of the OECD (2018) which weighted more on the theorical aspect of the Official Development Assistance (ODA) as a factor deepening fragility situations. Finally, it reveals the polysemic nature of fragility whose indices considered separately, allow a better understanding of its complexity for sound recommendations.

The rest of the paper is organized as follows. Section 2 illustrates some stylized facts. Section 3 explores the existing literature. Section 4 exposes the empirical strategy. Section 5 presents discusses the results. Section 6 concludes with some suggestions of economic policies.

\section{Some stylised facts}

Three stylized facts emerge from the observations of institutions and fragility in Africa.

\subsection{Institutional quality remains very poor in Africa}

Africa remains in the queue of the major democratic and regulatory changes occuring around the world due to its institutional weaknesses (Graphic 1). Even though the political stability has 
somewhat evolved lying at -0.54 , the governance efficiency has had a less favorable figure with 0.72. Some countries such as Kenya, Ghana, Senegal and Nigeria have adopted innovative legislative laws providing autonomy to the electoral system with the implementation of independent electoral commissions. However, the quality of regulation and the legal framework have less inticing indices. Moreover, these improvements have been carried out with the signature of the African chart on the harmonization of national laws by the African parliament. The fight against corruption intensified in many countries bringing along more confidence to foreigns investors.

\section{Graphic 1: Governance indicators in Africa (Annual average 1996-2018)}

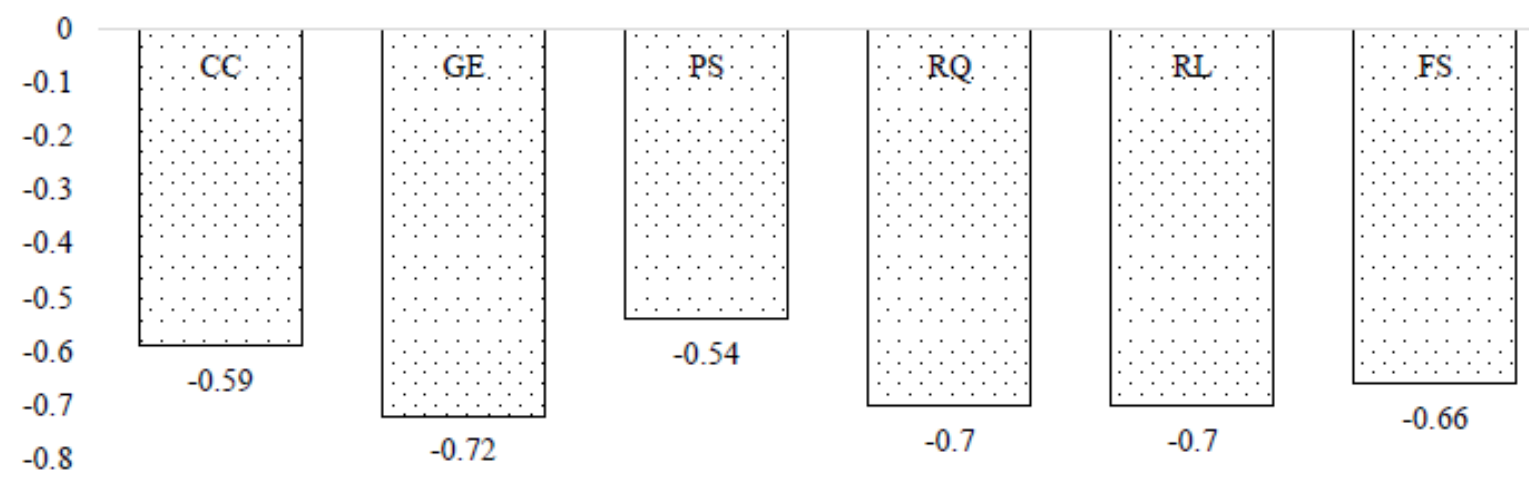

Notes: CC: Corruption Control; GE: Government Efficiency; PS: Political Stability; RQ: Regulation Quality; RL: role of law; FS: Freedom of Speech.

Source: Authors, from the WGI (2018).

There are differences at the sub-regional level, (Graphic 2). Northern Africa for instance has a better institutional performance due to the improvement of governance, political stability, macroeconomic and political reforms as well as a growing economic home demand. This improvement is the result of the emergence of a middle class and the increase of urbanization. This sub-region is followed by West African sub-region. Eastern Africa however experiences a poor institutional performance. This observation contrasts the policies implemented by the leaders in the said sub-region. Indeed, Rwanda, Kenya and Liberia are often cited as examples of countries having strong institutions. 
Graphic 2: Evolution of institutional indices in the African sub-regions.

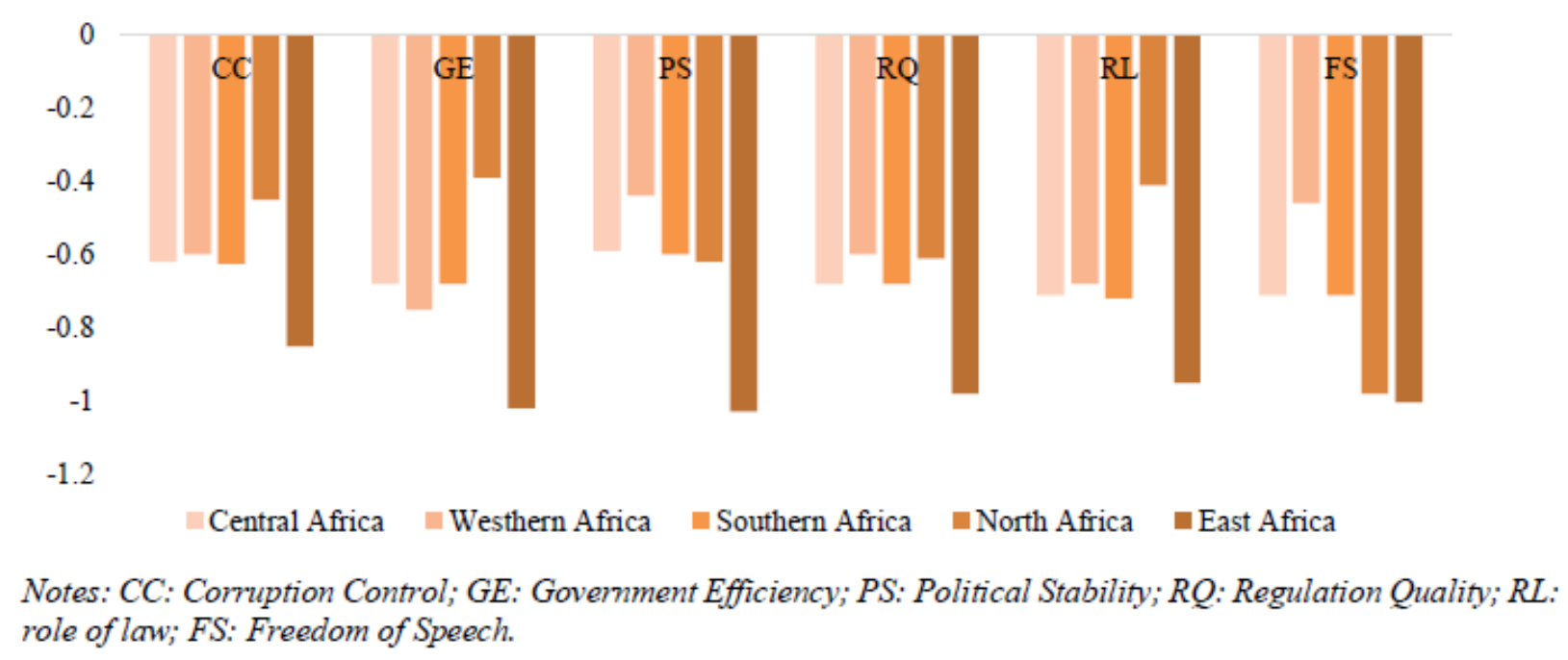

Source: Authors, from the WGI (2018).

\subsection{Fragility remains persistent and heterogeneous in Africa}

According to the State fragility index computed on a 20 points scale, Africa is a fragile continent. In spite of the drop observed (11.65 points in 1995 to 9.57 points in 2016), the African continent still has more fragile countries. For example, over the 50 world most fragile countries in 2016, 35 were African. Inter-regional comparison places west Africa, Austral Africa and Central Africa among the most fragile. The culprits being civil violences, armed conflicts, poverty, the debt burden and income inequalities. However, Northern and Eastern Africa recorded less instability factors. The fragile situation in Africa declines a double analysis. First, the contingencies of investment and institutional sustainability raise both the issue of the governance and security deficit. Second, the low diversification and structural transformation of African economies predispose countries to fragility when exposed to externalshocks. In average (1995-2016), some countries as Maurice (8.9), Botswana (10.95), Tunisia (12.01) and Morocco (12.3) stand out because of the resilience of their relatively diversified economies. Others, as Chad (15.85), DRC (17.02) and Somalia (18.23) are fragile. 
International Journal of Social Science and Economic Research

ISSN: 2455-8834

Volume:06, Issue:07 "July 2021"

Graphic 3: Evolution of fragility indices in Africa

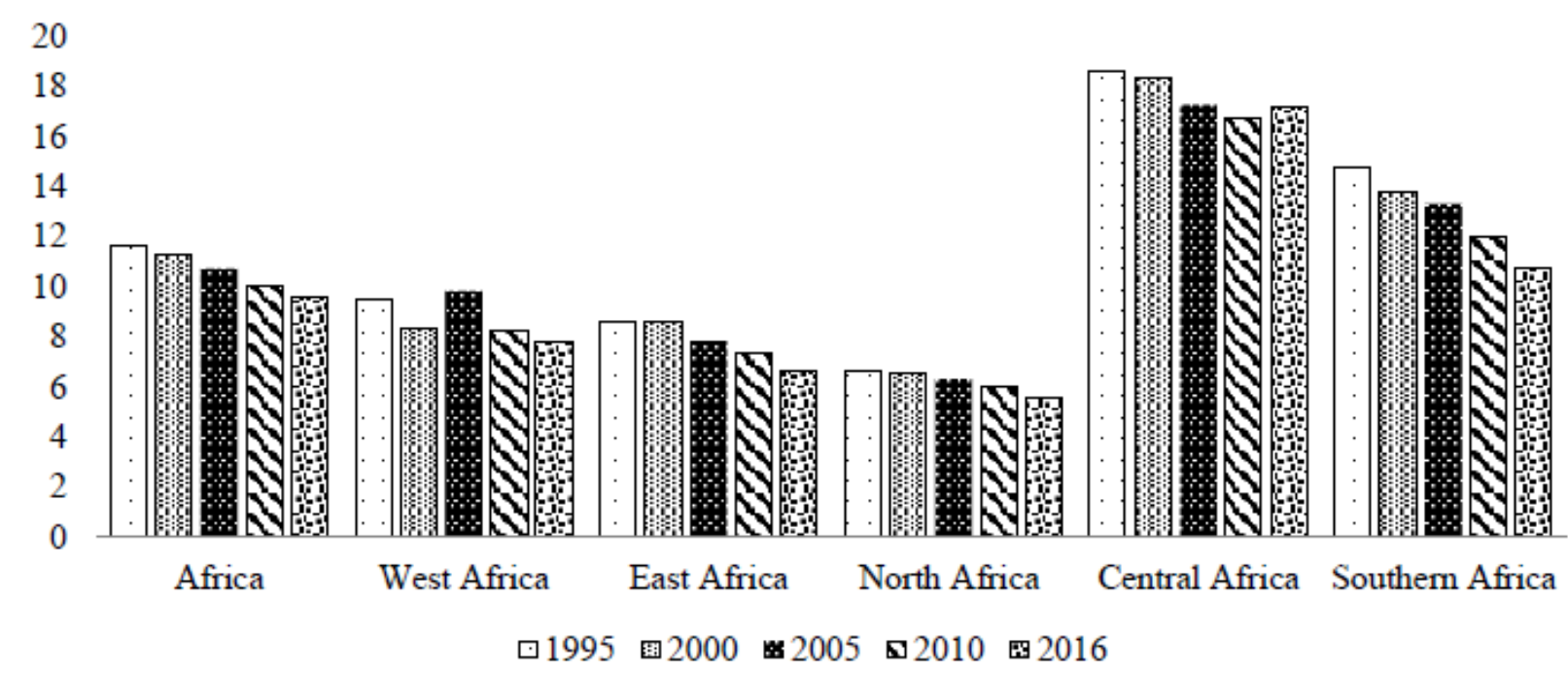

Source: Authors, from SFI (2017).

\subsection{Institutional quality and fragility are correlated}

The evolution of institutions and fragility show a wide gap (Graphic 4). Institutional inefficiencies have negatives values whereas the global fragility index ranges from 9.80 to 12 . Nevertheless, a contrasted trend showed up translated by the volatility and fluctuations of the institutional index. The fragility pic of 2009 can be understood as the consequences of the 2008 financial crises where both exports from Africa to the rest of the world as well as the inflows of FDI. Besides that, the socio-political crisis that rocked the Maghreb in the same period has considerably weaken the resilience capacity of the countries belonging from that part of the continent. The interlinkages between the both variables do not easily read out from the gap observed in their evolution. That's the reason why correlation between the both variables are justified by the graphic 4.b showing a positive interdependency between institutions and fragility. Indeed, the poor quality of institutions in Africa seems to increase the continent's fragility. 
International Journal of Social Science and Economic Research

ISSN: 2455-8834

Volume:06, Issue:07 "July 2021"

\section{Graphic 4: Trend and correlation between the global institutions and fragilities in Africa}

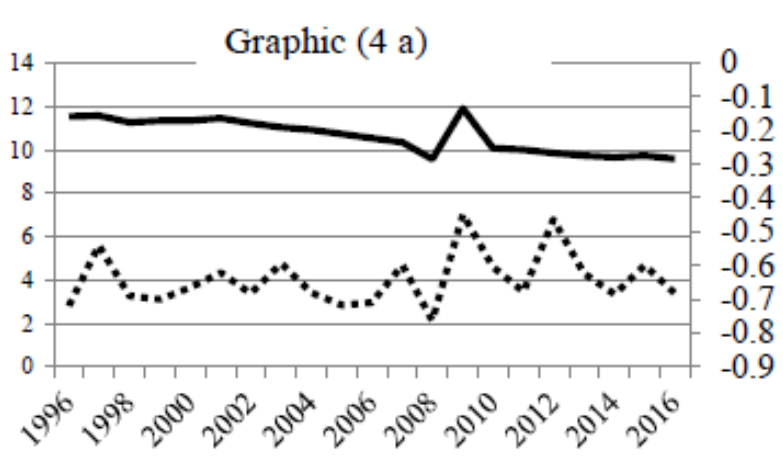

Fragility index

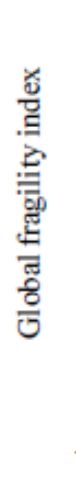

$-1$
Graphic (4 b)

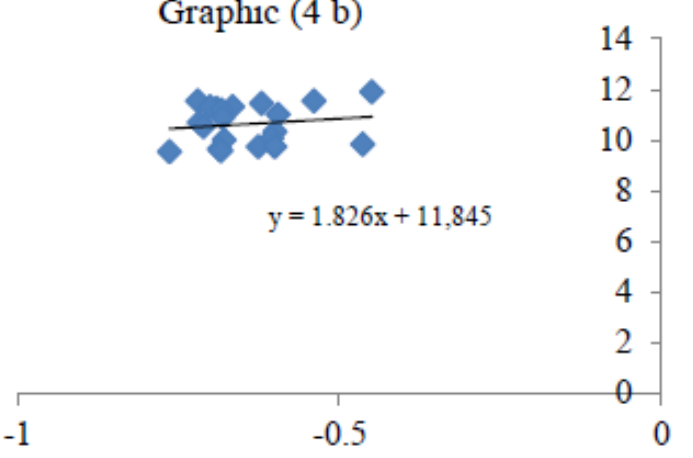

Global institutions index

Source: Authors, from WGI (2018) and SFI (2018).

\section{Literature review}

This section highlights the conceptual framework of fragility, essential to theorical understanding and empirical evidence of fragility effects.

\subsection{Fragility: a polysemic notion}

According Brook (2005), fragility reveals the pressure that breeds conflicts, instability, and crises stemming from the occurrence of changes and events. Newman (2009) considers it as the relative entier threats and risks. Bertocchi and Guerzoni (2010) define fragility as the unability to provide basic services and necessary public utilities, poor governance, persisting poverty, absence of territory control, tendency to conflicts and wars. For Carment et al., (2011) State fragility can be understood through three approaches : (i) the State authority accounts forfragility through the flow of refugees, conflicts, the ethnolinguistic differences, poverty, the weak structural innovation, the unequal distribution of income, the inefficiency of governance and the demographic pressure ; (ii) the Economic capacity undercores fragility vide the conditions that people face, the level of democracy, disasters and natural resources; (iii) the Elite Legitimacy explains fragility by the violation of human rights, the poor economic performance and corruption. For the OECD (2017), « a State is fragile when the government and State functions do not have the means and/or the political will to ensure security and the protection of its citizens, to efficiently manage public affairs and fight poverty in thepopulation».

\subsection{Institutions and fragilities: a theorical deduction}

The theorical framework of fragility analysis roots back to the seminal work of Todaro (1969) 


\section{International Journal of Social Science and Economic Research}

ISSN: $2455-8834$

Volume:06, Issue:07 "July 2021"

which pointed out, the role migrant remittances in reducing recipient households' poverty. Later on, based on the external financial flows (migrant remittances, Official Development Assistance, Foreign Direct Investments) and the existing correlations priorizitingfragility situations leading to violence, inequalities, social anomie and environment degradation, Nay (2013) and Azariadio (1997) respectively suggested the fragile State theory and the fragility trap theory.

The emergence of the New Institutional Economy (NIE) hypotherized by Acemoglu et al., (2005), Clague et al., (1996) and North (1990), has allowed to highlight importance of institutions in the growth and economic development process of countries. Their non- consensual impact led to the rise of two different views pertaining to State fragility: Institutionalenvironment ${ }^{4}$ and institutional arrangements (Davis and North, 1971). The first (microeconomic), builds on the transactions organization modes, the balance between the said modes and their compared efficiency (Williamson, 2001; Coase, 1991). The second (macroeconomic), explores the nature and the role of institutions (Aoki, 2001; North, 2005). These two views have led to the occurrence of two opposite approach of institutions. An optimistic approach that considers institutions as mechanisms reducing State fragility through the increase of investments, the efficient allocation of resources, the dynamic and innovative attractiveness of entrepreuneurs, the business competitiveness, the reduction of unemployment, poverty and conflicts through technology transfer and the improvement of efficiency (Adams et al., 2017). A pessimistic approach that sees institutions as mechanisms increasing State fragility through conflicts and instabilities coming along with damaging consequences such as violence, institutional weaknesses, migrations, humanitarian crises and poverty (Romuald, 2011).

The NIE allowed to identify two types of institutions. Formal institutions which is a set of contracts, written and explicit political, legal and economic rules whose execution is insuredby a political entity generally the State or its administration and informal institutions consisting of customs, conventions, codes or standards in force in a society. Noticing the complexity of their measure and moreover the scarcity of empirical works, informal institutions are not considered is this study.

\subsection{Institutions and fragilities: an empirical synthesis}

The empirical evidence of institutional quality on fragility are complex and non- consensual. Precisely, institutions can stimulate (Sobek, 2010), hinder (Sambanis, 2001) or have no significant effect over fragility (Roberts \& Parks, 2007). The lack of consensus accounts for the size of the sample, the methodology used and the content of fragility.

Englebert (2000), Clapham (1996) showed that the lack of credibility from citizens towards institutions is a source of political violence thereby breeding State political fragility. Valling \& 


\section{International Journal of Social Science and Economic Research}

ISSN: $2455-8834$

Volume:06, Issue:07 "July 2021"

Moreni-Torres (2005), Reynal-Querol (2002a, b), Hegre et al., (2001), Ellingsten (2000) found that a partial democratic regime fuels security fragility more than an autocratic regime. Kaplan (2008) purpoted that State fragility comes from the weaknesses of institutions and the absence of social cohesion. This social cohesion leads to an erosion of trust and to a higher risk of conflict among various social entities. Stewart and Brown (2009) underscored that institutional dysfunctions and conflict situations increase State fragility. Reno (2011) concluded that bad governance and poor institutions interact, and yield armed violence and deepen societal and institutional fragilities vide political pressures, social demands and demonstrations. Bertocchi (2012) showed that the ethnic subdivision, revolutions and civil freedoms lead to further fragility. Theisen et al., (2013), Sobek (2010) on their own demonstrated that poor quality institutions pave the way to more vulnerability to climate change and amplify the social fragility through two different aspects. The first reveals the disruption of resources supply leading to shortages and the second deals with the increase of natural disaster and the risk of population displacement. Rivera (2016), Wan-Hai (2015), Romuald (2011) found that institutional weaknesses push towards societal, economic and environmental fragilities in low income countries through interpersonal violence, and the increase of drugs and arms trafficking.

Torras and Boyce (1998), Dryzek (1987) working within the framework of developed and developing countries found the same conclusion that the institutional structure helps to mitigate environmental fragility. Bazilian and Chattopadhay (2016), Reynal-Querol (2005) showed that institutions and governance reduce the security fragility of States in a legal framework that drives out violence. Farzin and Bond (2016), Bernauer and Koubi (2009), Harbaugh et al. (2002) found that good democratic institutions participate to the reduction of environmental fragility by limiting non eco-freindly activities. Adam et al., (2017) working on a sample of 38 African countries notice that a high level of democracy and a sound bureaucratic quality reduce environmental fragility. More recently, Farzanegan and Markwardt (2018) find that democracy favors the mitigation of environmental fragility. At contrario, Roberts and Parks (2007) and Scruggs (1998) studying developed and developing countries, find no significant effect of democratic institutions' quality over environmental fragility assessed through carbon emissions.

Three learning's draw attention in this literature: first of all, the works separately consider the effects of institutional quality on economic fragility. This identifies the framework of the phenomenon being studied. Next, due to their complex nature, any analysis of the effects of quality institution should be global for a better mastering of the determinants of countries' resilience. Institutions would summarize the need of an institutional integration including the strengthening of countries' resilience. The issue of the complementarily between institutions and fragility has been renewed by a literature oriented towards NIE. Eventually, the non- consensual conclusions of the empirical works justify the need of further investigations in the context of 
International Journal of Social Science and Economic Research

ISSN: 2455-8834

Volume:06, Issue:07 "July 2021"

increasing fragility situations insofar as the literature undermines the importance of individual fragility indicators.

\section{Model, estimation technique and data}

\subsection{Empirical model}

The model is inspired from the works of Adam et al., (2017) and Rivera (2016) who hypotherized the effects of institutions on fragility. This model is described by equation 1 .

$$
\text { Fragilities }_{i t}=\alpha_{0}+\beta \text { Institutions }_{i t}+\gamma X_{i t}+\mu_{t}+v_{i}+\varepsilon_{i t}
$$

With Fragilities, the column vector of dependent variables featuring the composite index andthe five disaggregated indices. The fragility composite index of the Fund For Peace (FFP) steps on quantitative approaches to measure the fragility. The methodology comes into two stages: On the one hand, examination of fragility contexts building on facts such as political unrests, armed conflicts, and deadly disasters. On the other hand, the compilation of information to define a specific index. A Principal Component Analysis (PCA) has been run for each particular dimension of fragility. Fragilities range from extreme fragility $=1$, to high fragility $=2$, average fragility $=3$, weak fragility $=4$, minimal fragility $=5$ and finally the absence of fragility $=6$. We then process with the Tukey test to analyze the variance allowing to identify the characteristics of fragility. The five dimensions of fragility are considered namely: $(i)$ the economic dimension approached by the economic efficiency of countries, considers the GDP/capita, exportations of raw material, manufactured goods, the net oil production/consumption and raw material prices fluctuations; (ii) the political dimension approximated by the political regime, the political instability, democracy, autocracy and ethnicity ; (iii) the societal dimension calculated through human development index, the protection of human capital, the education level and life expectancy; (iv) the security dimensioncaptured by terrorist attacks, the number of civil wars and armed conflicts; (v) the environmental dimension consisting of climate change, air quality and the rate of water supply.

The fragility index presents two limits. The first is the lost of information when applyingthe PCA and the second is related to the global fragility index computed. Given that fragility strikes regions differently, it would be preferable to opt for an intra country approach.

The composite fragility index has three advantages. The first provides information on a large panel of African countries. The second builds on the time horizon and the last relates to the indicators retained (SFI, 2019; OECD, 2018). The third is that, the indicators used are 


\section{International Journal of Social Science and Economic Research}

ISSN: 2455-8834

Volume:06, Issue:07 "July 2021"

multidimensional. Contrary to the Economic Vulnerability Index of the Foundation for International Development Studies and Research which takes account the economic risk of States and uses indicators of high instability, the State Fragility Index combines economic, political, social, security and environmental indicators on a scale that takes into account the level of fragility depending on whether it's low, medium or extreme (McKay and Thorbecke, 2019). For Gnangnon (2017), the economic vulnerability index provides more information about the macroeconomic shock a country can bear. It's limited to measure fragility associated with macroeconomic disruptions, which in many cases are at the level of the continued decline in economic growth. The World Bank's fragility index presents a fundamental limitation expressed by the indicators contributing to its determination. Specifically, the fragility observed in terms of political stability and the degree of conflict is inherent in each country.

Institutions is a matrix of institutional quality that integrates : (i) the regulation quality (capacity of public authorities to elaborate and implement development policies en favor of the private sector); (ii) corruption (use of public funds to achieve personal enrichment including grand and petty corruption, « otage-taking » of the State by the elites and private interests); (iii) the legal framework (the confidence level of citizens, the respect of contracts, of police and courts jurisdictions, the perception of crimes and violence); (iv) the term in office of the Chief executive, reveals the number of years spent by the leader in office. Indeed, some decision rulesare necessary to deal with half years. The years spent in power are reckoned as from January 1 of time the leader took over the office; $(v)$ the duration in office of political party of Chief Executive. It's a variable relating to the time spent in office by the leader's party. This time is usually reckoned as from January 01 if the party's name changes. However, in some cases, the party's executive, its members and its structure remained unchanged after a name change; (vi) the regime's duration showing the numbers of years the regime spent in power; (vii) the autocracy indicator ranging from -10 to 0 that is, a total of 11 points where -10 stands for an absolute dictatorship. Featuring the democracy and autocracy indicators, Polity IV provided the Polity II indicator ranging between -10 and 10 which better represents a political regime. Following the works of Barro (1999), we converted the data into binary say 0 and 1.

$X$ is the control variables' vector including: $(i)$ the market size that represents the GDP/capita. According $\mathrm{La}$ and $\mathrm{Xu}$ (2017), an increase of GDP/capita fosters the economic resilience to shocks and mitigates fragility; (ii) The Gross Fixed Capital Formation (GFCF) captured by the accumulation of physical capital is an indicator of fragility augmentation (Baliamoune-Lutz, 2009); (iii) FDI measures the inflows of Foreign Direct Investments pertaining to the GDP. According to Ongo-Nkoa (2019), FDI flows are development vectors. Their high level of fluctuation increases the occurrence of exogenous shocks and more implicitely the fragility (Ongo Nkoa and Song, 2018); (iv) the human capital approached by the rate of high school 


\section{International Journal of Social Science and Economic Research}

ISSN: $2455-8834$

Volume:06, Issue:07 "July 2021"

enrolments, facilitates the integration of new technologies and curves down fragility. (Cuaresma et al. 2020); (vi) natural resources measured by the overall production yield related to GDP. It mainly consists of oil, natural gas, minerals and gemstones. For Hugon (2009), the dependence to natural resources rather increases the occurrence probability of conflicts as well as State fragility.

Therefore, $i$ and $t$ indices respectively provide information's on countries and periods considered; $\mu$ it takes into account the fixed temporal effect common to all countries, and $\varepsilon$ it is the term error.

The estimated model is specified as follows:

$$
\begin{aligned}
& \text { Fragilities }_{i t}=\alpha+\beta \text { Institutions }_{i t}+\beta_{1} \text { Market_size }_{i t}+\beta_{2} \text { GFCF }_{i t}+\beta_{3} F D I_{i t} \\
& +\beta_{4} \text { Natural_resorurces }+\beta_{5} \text { Human_capital }{ }_{i t}+\mu_{t}+v_{i}+\varepsilon_{i t}
\end{aligned}
$$

In other to enlighten the effects of institutional quality on the desaggregrated indices, we substituted each time the dependent variable by the considered fragility.

\subsection{Estimation technique}

For a better use of panel data, we processed with the Two Stage Least Squares (2SLS) which fits when at least one independent variable is endogenous in a linear regression or when an endogenous variable is measured with error. In what case the said variable and the error termwill be correlated. A good estimation of such a model requires the use of instrumental variables. For an endogeneity issue, it is rather advised to deal with the Generalized Method of Moments (GMM). However, notwithstanding the evolution of data from fragility indices, we notice a very few fluctuations translating the less influence of lagged variables on current ones. Hence, we forgwent that approach. The robustness of the results is achieved by the model estimation through a probit analysis on panel data. This approach allows to solve the issue relating to the measure of the dependent variable. We then hypotherize that fragility has a binary form. That is, the considered fragility takes 0 if its index is lower or equal to 6 and 1 if greater than 6 . Through this approach, the probit yields better results compared to those obtained by the 2SLS. Under the null hypothesis, the model is stable hence, the long period considered has no effect on the awaited results.

\subsection{The data}

Macroeconomic data are derived from the World Development Indicators (2018). FDI flows are drawn from the United Nations Conference for Trade and Economic Development (UNCED). 
International Journal of Social Science and Economic Research

ISSN: 2455-8834

Volume:06, Issue:07 "July 2021"

Fragility-related data come from the State Fragility Index (2016) of the Think Tank Fund For Peace of the OECD (2018). Institutional data spring from the World Governance Indicators (2018), and from Polity IV (2018). The sample is made up of 51 African countries (Table 1). Bound by the availability of data for the whole variables, the study spans over the period 19952018.

\section{Table 1 : List of Countries}

Angola, Burundi, Cameroon, CAR, Gabon, Equatorial Guinea, DRC, Congo, Chad, Benin, Burkina Faso, Capo Verde, Ivory Cost, The Gambia, Ghana, Guinea, Bissau Guinea, Liberia, Mali, Niger, Nigeria, Senegal, SierraLeone, Togo, Lesotho, Madagascar, Mozambique, Namibia, Swaziland, South Africa, Zambia, Zimbabwe, Tanzania, Uganda, Algeria, Egypt, Lybia, Mauritania, Morocco, Tunisia, Botswana, Comorus, Djibouti, Erythrea, Ethiopia, Kenya, Malawi, Mauritius Island, Rwanda, Somalia, Sudan

Source: Authors.

Descriptive statistics show weak variations (Table 2). It is admitted that when data weakly fluctuate, the results mostly converge.

Table 2 : Descriptive statistics

\begin{tabular}{|c|c|c|c|c|c|}
\hline Variables & Observations & Means & Std. Dev. & Minimum & Maximum \\
\hline Global fragility & 1100 & 6.552 & 4.615 & 0.166 & 41.03 \\
\hline Economic fragility & 1100 & 2.447 & 0.954 & 0.09 & 3.5 \\
\hline Political fragility & 1100 & 1.582 & 0.913 & 0.23 & 3 \\
\hline Societal fragility & 1100 & 2.296 & 0.734 & 0.41 & 3 \\
\hline Security fragility & 1100 & 1.015 & 0.840 & 0.15 & 3 \\
\hline Environmental fragility & 1014 & 26.468 & 27.251 & 0.25 & 187.983 \\
\hline Market size & 1166 & 3.185 & 7.433 & -1.924 & 26.798 \\
\hline$G F C F$ & 1131 & 4.991 & 8.857 & -62.075 & 149.973 \\
\hline Human capital & 944 & 42.780 & 25.496 & 5.164 & 121.611 \\
\hline Natural resources & 969 & 137.213 & 393.147 & 0.18 & 1992.273 \\
\hline$F D I$ & 1153 & 5.171 & 10.271 & -82.892 & 161.823 \\
\hline Corruption & 1166 & -0.6949 & 0.653 & -2.668 & 1.056 \\
\hline Rule of Law & 1166 & -0.708 & 0.656 & -2.665 & 1.000 \\
\hline Regulation quality & 1166 & -0.7432 & 0.626 & -2.479 & 1.130 \\
\hline Democracy & 1034 & 3.122 & 4.148 & -88 & 9 \\
\hline Regime duration & 1034 & 11.259 & 12.393 & 4 & 59 \\
\hline Term in office of the Chief executive & 1020 & 10.928 & 9.476 & 1 & 43 \\
\hline Duration in office of political party of Chief Executive & 1034 & 12.151 & 12.176 & 3 & 46 \\
\hline Institutions & 1052 & -0.921 & 0.503 & -2.227 & 0.107 \\
\hline
\end{tabular}

Source : Authors.

The correlation matrix (Table 3) show weak interlinkages, indicating an absence of multicolinearity between the dependent variable and the independent variables. 
International Journal of Social Science and Economic Research

ISSN: 2455-8834

Volume:06, Issue:07 "July 2021"

Table 3 : Correlation matrix

\begin{tabular}{|c|c|c|c|c|c|c|c|c|c|c|c|c|c|c|}
\hline & Fragilit & MSize & $F D I$ & GFCF & $H C$ & $N R$ & Corru & $R L$ & $R Q$ & Demo & RDur & TOCE & DOPPC & Inst \\
\hline Fragility & 1 & & & & & & & & & & & & & \\
\hline MSize & $-0.07 *$ & 1 & & & & & & & & & & & & \\
\hline$F D I$ & 0.03 & $-0.07 *$ & 1 & & & & & & & & & & & \\
\hline$G F C F$ & -0.03 & 0.08 & $0.26^{*}$ & 1 & & & & & & & & & & \\
\hline$H C$ & 0.02 & $0.16^{*}$ & -0.02 & $-0.12 *$ & 1 & & & & & & & & & \\
\hline$N R$ & $0.10^{*}$ & $0.70^{*}$ & $-0.07 *$ & 0.04 & $0.24 *$ & 1 & & & & & & & & \\
\hline Corr & $0.21 *$ & -0.03 & $-0.08^{*}$ & -0.03 & $0.55^{*}$ & $-0.12 *$ & 1 & & & & & & & \\
\hline$R L$ & $0.18^{*}$ & $-0.06^{*}$ & $-0.09 *$ & -0.01 & $0.50^{*}$ & $-0.13^{*}$ & $0.84 *$ & 1 & & & & & & \\
\hline$R Q$ & $0.17 *$ & -0.04 & $-0.11 *$ & -0.03 & $0.57 *$ & $-0.17^{*}$ & $0.87 *$ & $0.85^{*}$ & 1 & & & & & \\
\hline Democ & $0.14^{*}$ & $-0.23^{*}$ & 0.03 & 0.02 & $0.13^{*}$ & $-0.17^{*}$ & $0.23 *$ & $0.20^{*}$ & $0.19^{*}$ & 1 & & & & \\
\hline RDur & 0.05 & $0.28^{*}$ & 0.03 & $0.07 *$ & $0.36^{*}$ & $0.23^{*}$ & $0.28 *$ & $0.29 *$ & $0.25 *$ & $-0.10 *$ & 1 & & & \\
\hline TOCE & $0.15^{*}$ & $0.40^{*}$ & -0.02 & -0.09 & 0.04 & $0.40^{*}$ & $-0.17^{*}$ & $-0.12 *$ & $-0.11 *$ & $-0.32 *$ & $0.36^{*}$ & 1 & & \\
\hline$D O P P$ & 0.01 & $0.12 *$ & 0.03 & 0.02 & 0.04 & $0.07 *$ & $0.07 *$ & $0.11 *$ & $0.22 *$ & $-0.11 *$ & $0.19^{*}$ & $0.37 *$ & 1 & \\
\hline Inst & $0.17^{*}$ & $0.11^{*}$ & -0.07 & 0.01 & $0.53 *$ & -0.12 & $0.86^{*}$ & $0.94 *$ & $0.87 *$ & $-0.14 *$ & $0.31 *$ & 0.05 & $0.21 *$ & 1 \\
\hline
\end{tabular}

Notes: GFCF: Gross Fixed Capital Formation; HC: Human Capital; RL: Rule of Law; NR: Natural Resources; RQ: Regulation Quality; TOCE: Term in office of the Chief executive; DOPPC: Duration in office of political party of Chief Executive; Ethl: Ethnolinguistique subdivision.

Source: Authors.

\section{Results}

This section reports and discusses the empirical results from the basic model and robustness analyses.

\subsection{Baseline Results}

The results reported in Table 4 show that the coefficients of institutional variables have positive and significant effects on the fragilities following the estimation by the Two-Stage Least Square (2SLS). The coefficient of determination is average 0.673 indicating a good quality of models adjustment and a good specification of explanatory variables. Precisely, corruption, legal framework, regulation quality, Term in office of the Chief executive and Duration in office of political party of Chief Executive increase global fragility in Africa. An explanation is that, institutional quality in Africa is relative. Thus, these factors widen income inequalities and the social exclusion of minority thereby bringing along poor living standard to the people. It subsequently, entails risky fundings by modifying behaviors such pressions, claimings and demonstrations. These results take into account the transformation of standards living, ideologies, beliefs, and the environment in which live people. So, the institutional quality brings along administrative slowness, increases the opportunity cost of firms and households but hinders the competitiveness of economic activities. These results line up with those of Bertocchi 


\section{International Journal of Social Science and Economic Research}

ISSN: $2455-8834$

Volume:06, Issue:07 "July 2021"

\& Guerzoni (2010) and Reno (2011) who concluded that the bad governance of poorinstitutions further deepens fragilities. The corollary of the above assertion lies in the fact that, the African institutions are seen to be neck deep in corruption and corrupt activities, they lack the required effective state economic strategy to enhance the living standard of the people to the extent that, poor governance, poverty, incessant break down of law and order, amongst others are obvious in the African public life. Another explanations of fragility State is the rule of Law that troubles the state. These includes unemployment, political instability, lack of socialtrust among various ethnic, religious and social groups, bad government, inability to effectively exercise jurisprudence over state territory, thereby, leading to the recent conceptualization of ungoverned territory. These results aren't consistent with Farzanegan and Markwardt (2018), Adam et al., (2017). For example, the term in office of the Chief executive and the duration in office of political party of Chief Executive increase environmental fragility. A possible explantion is that the respect of environmental standards pertains to urban towns and mainly residential quarters. However, in rural area, the extreme poverty rocking people lead them to carry out less eco-friendly activities such as the extraction of natural resources, deforestation, and traditional farming techniques like burning that deepen environmental fragility. These results are consistent with those of Theisen et al., (2013), Sobek (2010) who found that the poor institutions increase the vulnerability of developing countries towards climate change.

Democracy have a negative and statistically significant effect on fragilities in Africa. At least, three justifications can be put in forward. Firslty, democracy lowers the costs of political participation of organized labor, allowing labor unions to obtain a privileged position in the policy process. Secondly, democracy encourages unionization, centralized wage bargaining, and minimum wages, which reduce wage dispersion. Thirdly, Democracies should also guarantee broad access to property rights. With well-defined property rights and broad access to them, the poor have the possibility to gain access over improved or produced assets by facilitating the development of efficient market-based economies and opening up markets and institutions, which also prevent the elite from erecting entry barriers and enjoying markets with monopoly power. Thus, democracy increases competition among politicians for citizen support. This causes governments to invest more in public services, such as education, reducing fragilities. Democracy is believed to place a relatively high value on human life and the quality of life. Thus, democratic procedures force government to take a broader (and, perhaps, longer-term) view that speaks to the interests of society as a whole. In fact, democratic institutions areresponsive in the sens that, they act on society's expressed concerns including environmental concerns, and accountable for how well they perform. Indeed, in Africa, may countries suffer periods of violence and, therefore, the mere fact of having civil liberties and freedom does not seem to protect them against violence. In principle, political rights and civil liberties should reduce the risk of armed conflict because they attenuate discrimination and repression. This result is 


\section{International Journal of Social Science and Economic Research}

ISSN: $2455-8834$

Volume:06, Issue:07 "July 2021"

consistent with Schumpeter (1942) and (Rodrik, 1999) who find that, democracie reduces levels of inequality in developed and developing countries.

The contributive variables to these results are human capital, natural resources, FDI, Market size and GCFC. They affect fragilities, inducing higher cost-of-living that hinder competition, consolidates bank risks exposition, inefficient management of rents, and conflicts amplified by the resurgence of terrorist groups that have for objective, the monopolizing of resource-rich areas. Natural resources increase fragility in Africa. Their exploitation creates a financial rent captured and controlled by a political class. Their high levels encourage the emergence of conflict, a source of fragility. Also, poor governance of extractive and non-extractive natural resources penalizes the creation of decent jobs. In some African countries, resource rents do little to contribute to the development of basic social services. These results corroborate those of Collier and Hoeffler (2004. Thus, the abundance ofnatural resources leads countries to four traps, then two are directly related to the State fragility(conflict and poor governance) on the one hand, and poverty and the curse of natural resourceson the other (Collier, 2007).

\section{Tableau 4 : Effects institutional quality on fragilities in Africa}

Estimation technic: Two Stage Least Square

\begin{tabular}{|c|c|c|c|c|c|c|}
\hline & $\begin{array}{r}\text { Global } \\
\text { fragility }\end{array}$ & $\begin{array}{c}\text { Economic } \\
\text { fragility }\end{array}$ & $\begin{array}{l}\text { Political } \\
\text { fragility }\end{array}$ & $\begin{array}{c}\text { Social } \\
\text { sociale }\end{array}$ & $\begin{array}{l}\text { Security } \\
\text { fragility }\end{array}$ & $\begin{array}{c}\text { Environnemental } \\
\text { fragility }\end{array}$ \\
\hline \multirow{2}{*}{ Market size } & $-0.0630 * *$ & $-0.0636^{*}$ & $-0.058 * *$ & $-0.0214 *$ & $-0.036 * *$ & $-1.686 * * *$ \\
\hline & $(0.0431)$ & $(0.0113)$ & $(0.0126)$ & $(0.0104)$ & $(0.0094)$ & $(0.338)$ \\
\hline \multirow[t]{2}{*}{$G F C F$} & 0.0604 & $0.0167 * *$ & $0.0230 *$ & 0.00149 & 0.0147 & -0.0763 \\
\hline & $(0.0352)$ & $(0.0087)$ & $(0.0098)$ & $(0.0089)$ & $(0.0093)$ & $(0.180)$ \\
\hline \multirow[t]{2}{*}{ Human capital } & $-0.036 * *$ & $-0.0262 *$ & $-0.029 * *$ & $-0.0228 *$ & $-0.029 * *$ & $-0.188 * *$ \\
\hline & $(0.0277)$ & $(0.0072)$ & $(0.0073)$ & $(0.0072)$ & $(0.0058)$ & $(0.112)$ \\
\hline \multirow[t]{2}{*}{ Natural Resources } & 0.0088 & $0.0249 * *$ & $0.0025 *$ & $0.0040 * *$ & $0.0026^{*}$ & $0.0187^{* * *}$ \\
\hline & $(0.0005)$ & $(0.0014)$ & $(0.0001)$ & $(0.001)$ & $(0.0002)$ & $(0.00239)$ \\
\hline \multirow[t]{2}{*}{$F D I$} & $0.0713 * *$ & $0.0210 * *$ & $0.0264 *$ & $0.0029 * *$ & $0.0194 *$ & $0.0631^{*}$ \\
\hline & $(0.0394)$ & $(0.0097)$ & $(0.0104)$ & $(0.0080)$ & $(0.0104)$ & $(0.166)$ \\
\hline \multirow[t]{2}{*}{ Corruption } & $0.6301 * * *$ & $0.946^{*}$ & $1.395 *$ & $1.367 * *$ & $1.310^{*}$ & $1.376^{*}$ \\
\hline & $(1.634)$ & $(0.460)$ & $(0.654)$ & $(0.449)$ & $(0.658)$ & $(7.852)$ \\
\hline \multirow[t]{2}{*}{ Legal Framework } & $1.852 * *$ & $2.014 * * *$ & $1.562 * *$ & 1.203 & 0.529 & $1.414^{*}$ \\
\hline & $(2.466)$ & $(0.544)$ & $(0.525)$ & $(0.666)$ & $(0.476)$ & $(0.422)$ \\
\hline \multirow[t]{2}{*}{ Regulation Quality } & $1.120 * * *$ & $1.369 *$ & $1.604 * *$ & $0.750 * * *$ & $1.926 * * *$ & $1.147^{*}$ \\
\hline & $(1.856)$ & $(0.546)$ & $(0.539)$ & $(0.436)$ & $(0.422)$ & $(5.121)$ \\
\hline \multirow[t]{2}{*}{ Democracy } & $-0.308 * *$ & $-0.0622 *$ & $-0.076 * *$ & $-0.106 *$ & $-0.190 *$ & $-2.110 * *$ \\
\hline & $(0.403)$ & $(0.134)$ & $(0.196)$ & $(0.104)$ & $(0.221)$ & (1.388) \\
\hline \multirow[t]{2}{*}{ Regime Duration } & $0.0838 *$ & 0.00855 & 0.00795 & 0.00232 & 0.00837 & 0.0629 \\
\hline & $(0.0318)$ & $(0.0074)$ & $(0.0082)$ & $(0.0061)$ & $(0.0072)$ & $(0.120)$ \\
\hline \multirow[t]{2}{*}{ Term in office of the Chief executive } & $0.0114 *$ & $0.0452 *$ & $0.060 * * *$ & $0.0414 *$ & $0.0606 * *$ & $-1.327 *$ \\
\hline & $(0.0651)$ & $(0.0181)$ & $(0.0169)$ & $(0.0195)$ & $(0.0130)$ & $(0.658)$ \\
\hline
\end{tabular}




\section{International Journal of Social Science and Economic Research}

ISSN: $2455-8834$

Volume:06, Issue:07 "July 2021"

\begin{tabular}{lcccccc} 
Duration in office of political party of & $0.0483^{*}$ & $0.0402 *$ & $0.064^{* * *}$ & $0.0373^{*}$ & $0.0630^{* *}$ & $1.638^{* * *}$ \\
Chief Executive & $(0.0577)$ & $(0.0155)$ & $(0.0169)$ & $(0.0170)$ & $(0.0140)$ & $(0.649)$ \\
& $-1.400^{* * *}$ & $-3.541^{* *}$ & $-4.034^{* *}$ & $-2.403^{* *}$ & $-2.884^{* *}$ & $-1.061^{* *}$ \\
Institutions & $(2.543)$ & $(0.573)$ & $(0.582)$ & $(0.752)$ & $(0.527)$ & $(13.35)$ \\
& $1.405^{* * *}$ & $4.278^{* * *}$ & $3.551^{* * *}$ & $4.009 * * *$ & $3.632 * * *$ & $1.666^{* * *}$ \\
Constant & $(2.590)$ & $(0.739)$ & $(0.750)$ & $(0.571)$ & $(0.589)$ & $(9.923)$ \\
& 95 & 95 & 95 & 95 & 95 & 81 \\
\hline Observations & 51 & 51 & 51 & 51 & 51 & 51 \\
Number of countries & 0.677 & 0.678 & 0.600 & 0.633 & 0.685 & 0.769 \\
$R^{2}$ & & & & & \\
\hline
\end{tabular}

Notes: *;***** Threshold significances $10 \%, 5 \%$ and $1 \%$ respectively. ( ) : Robust Sd dev.

Source: Authors

Also, FDI have positive and statistically significant effects on the fragilities considered. They increase the global, economic, social, political, environmental, and security fragilities in Africa. These results are consistent with those of Özerdem and Podder (2011). Without being exhaustive, two explanations can be put forward. On the one hand, as a "market research" FDI, they do not serve the local market through job creation, do not improve competitive position and increase fragility. In fact, FDI induces a sustainability of dependence and incentives, rentseeking behaviours, political actions (discontents, risks of destabilization, financing of rebellions, deterioration of the quality of governance, contentious mobilizations) of environmental actions (risk effect by the anarchic extraction of natural resources). On the other hand, as a "resource-seeking" FDI, their investments are aimed at acquiring raw materials through activities that harm the environment. Thus, they increase environmental fragility by encouraging households to activities such as natural resource extraction, deforestation, and traditional agricultural activities. FDI significantly influences fragility by amplifying macroeconomic shocks and insecurity.

Nevertheless, human capital has negative and significant effect on the fragilities concerned in Africa. Precisely, schooling provides good manners and know-how to people thereby by giving them an autonomy in the fulfillment of their needs. In fact, education is a powerful driver of development and is one of the strongest instruments for reducing poverty and improving peace and stability. Education can mitigate these root causes of fragility, promote stability and bridge the gap between humanitarian assistance and development. Providing security to staff and students is the priority. It appears as a strong signal to the peoplethat its government is attempting to improve their lives, generating economic, political, and social stability by giving people tools with which they can resolve disputes peacefully, which can make them less likely to incur the risks involved in joining a rebellion. This result is consistent with findings of Tendetnik et al., (2018) in developing countries. The negative effect of the market size on the economic, societal, 
International Journal of Social Science and Economic Research

ISSN: 2455-8834

Volume:06, Issue:07 "July 2021"

and political and security fragilities accounts for the low level of income/capita favoring the development of illegal markets and activities. Therefore, GFCF increases economic and political fragilities due to a low level of training which is not favorable to a faster absorption of new technology and an effective return.

\subsection{Robustness analysis}

As a robustness check, we experiment with another estimation technique. Considering the common variables and/or data compilation, we analyze the robustness of results through a probit model. Overall, the fragilities (global, economic, political, social, security and environment) observed are statistically influenced by institutional variables (Table 4). Two explanations can be put forward. Firstly, environment institutional remains less favorable in Africa, because of the inefficiency of policy reforms, the failure to strengthen national institutions, the deterioration in the economic environment, due to sociopolitical instability and terrorist attacks, and difficulty in adjusting to lower commodity prices after the end of the commodity widespread price rises. Secondly, the level of democracy remains low despite the advent of multiparty politics in the early 1990s, showing the difficulty in transmitting the "Presidential scepter" as well as "the supreme aphrodisiac of the chief executive "as pointed out by Henry Kissinger, Nobel Peace Prize 1973. The sustainability of the regime and the term of office of the chief executive remain correlated and constitute common characteristics of most of the African countries, driven by the desire to return to authoritarianism and despotism, the questioning of the rule of law, the persistence of armed conflicts and the blows of States, poorlyorganized elections are originally of the fragilities observed.

Specifically, the significance levels change from one coefficient to another. In the probit as in the DLS estimations, the median is $1 \%$. The control variables used $(i)$ the robustness model, are identical to that of the base model. However, the robustness of the probit analysis does not question the results of the first estimation.

Table 5: Effects of institutional quality on fragilities in Africa.

Estimation technique: Probit

\begin{tabular}{|c|c|c|c|c|c|c|}
\hline & $\begin{array}{c}\text { Global } \\
\text { Fragility }\end{array}$ & $\begin{array}{c}\text { Economic } \\
\text { Fragility }\end{array}$ & $\begin{array}{l}\text { Political } \\
\text { Fragility }\end{array}$ & $\begin{array}{c}\text { social } \\
\text { Fragility }\end{array}$ & $\begin{array}{l}\text { Security } \\
\text { Fragility }\end{array}$ & $\begin{array}{c}\text { Environmental } \\
\text { Fragility }\end{array}$ \\
\hline Market size & $\begin{array}{c}-0.0072 * \\
(0.018)\end{array}$ & $\begin{array}{c}-0.0110 * * * \\
(0.024)\end{array}$ & $\begin{array}{c}-0.0676^{* * * *} \\
(0.020)\end{array}$ & $\begin{array}{c}-0.0542 * * \\
(0.020)\end{array}$ & $\begin{array}{c}-0.0823 * * * \\
(0.019)\end{array}$ & $\begin{array}{c}-0.0220 * * * \\
(0.043)\end{array}$ \\
\hline$G F C F$ & $\begin{array}{c}0.0338^{*} \\
(0.014)\end{array}$ & $\begin{array}{l}0.0260 \\
(0.016)\end{array}$ & $\begin{array}{c}0.0429^{*} \\
(0.017)\end{array}$ & $\begin{array}{l}-0.0129 \\
(0.017)\end{array}$ & $\begin{array}{c}0.0492 * \\
(0.019)\end{array}$ & $\begin{array}{c}-0.00855 \\
(0.019)\end{array}$ \\
\hline Human capital & $\begin{array}{c}-0.0112 * * \\
(0.012)\end{array}$ & $\begin{array}{c}-0.0491 * * * \\
(0.011)\end{array}$ & $\begin{array}{c}-0.0421 * * * \\
(0.010)\end{array}$ & $\begin{array}{c}-0.0515 * * * \\
(0.013)\end{array}$ & $\begin{array}{c}-0.0427 * * * \\
(0.0105)\end{array}$ & $\begin{array}{c}-0.0214 * * \\
(0.013)\end{array}$ \\
\hline
\end{tabular}


ISSN: 2455-8834

Volume:06, Issue:07 "July 2021"

\begin{tabular}{|c|c|c|c|c|c|c|}
\hline Natural resources & $\begin{array}{c}0.0239 * * \\
(0.002)\end{array}$ & $\begin{array}{c}0.0018 * * \\
(0.002)\end{array}$ & $\begin{array}{c}0.0011^{*} \\
(0.003)\end{array}$ & $\begin{array}{c}0.0097 * * * \\
(0.002)\end{array}$ & $\begin{array}{l}0.0046 \\
(0.003)\end{array}$ & $\begin{array}{c}0.0023 * * * \\
(0.003)\end{array}$ \\
\hline \multirow[t]{2}{*}{$F D I$} & $0.0326^{*}$ & $0.0419 *$ & $0.0507 * *$ & $0.00576^{*}$ & $0.0396^{* *}$ & $0.0137 * *$ \\
\hline & $(0.014)$ & $(0.017)$ & $(0.016)$ & $(0.015)$ & $(0.020)$ & $(0.017)$ \\
\hline \multirow[t]{2}{*}{ Corruption } & $3.016 * * *$ & $1.670^{*}$ & $1.831 *$ & $2.014 * *$ & $2.688 * *$ & $2.141 *$ \\
\hline & $(0.681)$ & $(0.704)$ & $(0.887)$ & $(0.755)$ & (1.039) & $(0.900)$ \\
\hline \multirow[t]{2}{*}{ Legal framework } & 1.884 & $3.508 * * *$ & $2.612 * *$ & $2.668 *$ & 1.036 & -1.063 \\
\hline & $(1.098)$ & $(0.977)$ & $(0.862)$ & $(1.161)$ & $(0.862)$ & $(1.191)$ \\
\hline \multirow[t]{2}{*}{ Quality regulation } & $3.049 * * *$ & $2.104 *$ & $2.213 * *$ & 1.243 & $3.549 * * *$ & 0.750 \\
\hline & $(0.680)$ & $(0.845)$ & $(0.774)$ & $(0.730)$ & $(0.801)$ & $(0.651)$ \\
\hline \multirow[t]{2}{*}{ Democracy } & -0.157 & -0.0702 & 0.149 & -0.213 & 0.303 & -0.273 \\
\hline & $(0.162)$ & $(0.232)$ & $(0.285)$ & $(0.164)$ & $(0.369)$ & $(0.194)$ \\
\hline \multirow[t]{2}{*}{ Regime duration } & $0.0393 * *$ & $0.0085 *$ & $0.0145^{* *}$ & $0.0043^{*}$ & $0.0075^{*}$ & $0.0099 *$ \\
\hline & $(0.0149)$ & $(0.011)$ & $(0.011)$ & $(0.011)$ & $(0.013)$ & $(0.014)$ \\
\hline \multirow[t]{2}{*}{ Term in office of the Chief executive } & $0.0427 *$ & $0.0935 * * *$ & $0.0737 * *$ & $0.0722 *$ & $0.0118 * * *$ & $0.0121 * *$ \\
\hline & $(0.029)$ & $(0.026)$ & $(0.023)$ & $(0.030)$ & $(0.028)$ & $(0.086)$ \\
\hline \multirow{2}{*}{$\begin{array}{l}\text { Duration in office of political party } \\
\text { of Chief Executive }\end{array}$} & $0.0268 *$ & $0.0836^{* * *}$ & $0.0875 * * *$ & $0.0755 * *$ & $0.122 * * *$ & $0.174 *$ \\
\hline & $(0.028)$ & $(0.023)$ & $(0.024)$ & $(0.027)$ & $(0.031)$ & $(0.088)$ \\
\hline \multirow[t]{2}{*}{ Institutions } & $7.151 * * *$ & $5.544 * * *$ & $6.078 * * *$ & $4.011 * * *$ & $5.440^{* * *}$ & $2.922 * *$ \\
\hline & $(1.165)$ & $(0.951)$ & $(1.041)$ & $(1.204)$ & $(1.172)$ & $(1.707)$ \\
\hline Observations & 95 & 95 & 95 & 95 & 95 & 81 \\
\hline Wald exogeneity test & - & 107.87 & 71.68 & 76.80 & 121.31 & - \\
\hline Wald exogeneity test $P$-value & - & 0.0000 & 0.0000 & 0.0000 & 0.0000 & - \\
\hline Log pseudo likelihood & 0.0993 & 0.2364 & 0.2224 & 0.2364 & 0.2904 & 0.1731 \\
\hline
\end{tabular}

Notes: *;*; *** threshold significance of $10 \%, 5 \%$ and $1 \%$ respectively. ( ) : Robust Std Dev.

Source: Authors.

\section{Conclusion and suggestions of economic policies}

This paper investigates the effects of institutional quality on fragilities in Africa. Noticing that institutional quality in Africa has weakly increased along the last three decades and the main ones concerned are fragile countries. Leaning on these two facts, we mobilized theoretical and empirical developments to build a model to test the hypothesis that institutions increase fragility in African countries. Several model variants were estimated by the Two Stage Least Square, from a sample of 51 African countries over the period 1995 to 2016. The originality ofour study in relation to the existing literature was to propose an analysis based on disaggregated indices of fragility. We have shown that this is the overall index or disintegrated, institutions increase the fragilities observed in Africa.

From its results, some non-exhaustive suggestions of economic policies can be made withthe aim to attenuate fragilities in Africa: (i) cleaning up institutional environment through the implementation of the rules economic, political and legal policies that attenuate fragility. Thus, Promotion of good governance policies in order to reduce institutional inefficiencies, boost 
International Journal of Social Science and Economic Research

ISSN: 2455-8834

Volume:06, Issue:07 "July 2021"

competitiveness in market systems, and to guarantee the protection of property rights; (ii) Consolidate industrialization strategies to modernize the transformation of natural resources, in order to invest financial resources from the exploitation of annuities in meeting vital needs; (iii) Strengthen security in high-risk and cross-border areas, in order to protect households from externally funded armed attacks that cause unrest in resource-rich regions; (iv) Develop willful eco-friendly policies to guaranty an effective ecological transition as an answer to the economic, social and environmental emergencies.

\section{References}

ACEMOGLU D., JOHNSON S. (2005), «Unbundling institutions». Journal of Political Economy, $\mathrm{N}^{\circ} 113(5), 949-995$.

ADAMS S., KLOBODU E., KWAME M. (2017), «Urbanization, Democracy, Bureaucratic Quality, and Environmental Degradation». Journal of Policy Modeling http://dx.doi.org/10.1016/j.jpolmod.2017.04.006

AOKI M. (2001), Towards Comparative Institutional Analysis. Cambridge (USA), MIT Press.

AZARIADIS, C., (1997), «The Economics of Poverty Traps, part one: Complete Markets». Journal of economic growth, 1(4), 449-486.

BAfD (2014), Remédier à la fragilité et renforcer la résilience, Banque Africaine de Développement, Abidjan, p.42.

BALIAMOUNE-LUTZ M. (2009), « Institutions, trade, and social cohesion in fragile states: Implications for policy conditionality and aid allocation», Journal of Policy Modeling, 31, 877890.

BANQUE MONDIALE (2011), Crime and Violence in Central America : A Development Challenge, Banque Mondiale, Washington, DC.

BANQUE MONDIALE (2014), Rapport sur le développement dans le monde 2011 : Conflits, sécurité et développement, Banque Mondiale, Washington, DC.

BAZILIAN M., CHATTOPADHYAY D. (2016), «Considering power system planning in fragile and conflict states». Energy for Sustainable Development, 32, 110-120.

BERNAUER T. et KOUBI V. (2009), «Effects of political institutions on air quality». Ecological Economics 68(5), 1355-1365. 
International Journal of Social Science and Economic Research

ISSN: 2455-8834

Volume:06, Issue:07 "July 2021"

BERTOCCHI G. (2012), « Growth, history, or institutions: What explains state fragility in subSaharan Africa? ». Journal of Peace Research, 49(6) 769-78.

BERTOCCHI G., GUERZONI A. (2010), Growth, History, or Institutions? What Explains State Fragility in Sub-Saharan Africa? Discussion Paper No. 4817 March 2010 IZA. CARMENT D., PREST S. et SAMY Y. (2011), " The causes and measurement of state fragility. Fragile States: Causes, Costs, and Responses? », Oxford Scholarship Online: WIDER Studies in Development Economics, 43-67.

CLAGUE C., KEEFER P., KNACK S. (1996), « Property and Contract Rights in Autocracies and Democracies ». Journal of Economic Growth, 1 (2), 243-76.

CLAPHAM C. (1996), Africa and the International System: The Politics of State Survival, Cambridge University Press, Cambridge.

COASE R.H. (1991), «The Institutional Structure of Production», Alfred Nobel Memorial Prize Lecture in Economic Sciences. Nobel Foundation: 12 pages. Reproduit dans American Economic Review, 82, 713-719.

COLLIER P., HOEFFLER A. (2004), « Greed and Grievance in Civil War», Oxford Economic Papers, 56(4), 563-595.

COLLIER P. (2007]), The Bottom Billion. New York: Oxford University Press.

CUARESMA J.C., FLORIAN H., LUCA O. (2020), «Fragility and the effect of international uncertainty shocks», Journal of International Money and Finance, https://doi.org/10.1016/j.jimonfin.2020.102151

DAVIS L.E., NORTH D.C. (1971), Institutional Change and American Economic Growth. Cambridge (UK): Cambridge University Press.

DRYZEK, J. S. (1987), Rational ecology: Environment and political economy.

DUNNE J.P., TIAN N. (2019), «Costs of civil war and fragile states in Africa», Review of Development Economics, 23(3), 1-18.

FARZANEGAN M.R. et MARKWARDT G. (2018), «Development and Pollution in the Middle East and North Africa: Democracy Matters», Journal of Policy Modelling, https://doi.org/10.1016/j.jpolmod.2018.01.010 
International Journal of Social Science and Economic Research

ISSN: 2455-8834

Volume:06, Issue:07 "July 2021"

ELLINGSTEN T. (2000), «Colorful community or ethnic witches brew?». Journal of Conflict Resolution, 44, 228-249.

ENGLEBERT P. (2000), State Legitimacy and Development in Africa, Lynne Rienner Publishers, Londres.

FARZIN Y. H., BOND C. A. (2006), «Democracy and environmental quality». Journal of Development Economics, 81, 213-235.

FRAGILITY STATE INDEX (2018), L'indice de fragilité des Etats, The Fund for peace, www. http://fundforpeace.org.

FEARON J. (2011), «Fragilité des États, indicateurs de gouvernance et risque de guerre civile », Revue d'économie du développement, 19(4), 153-186.

Gnangnon S. (2017), « Structural Economic Vulnerability, Openness and BilateralDevelopment Aid Flows», Economic Analysis and Policy, 53, 77-95.

HARBAUGH W. T., LEVINSON A., WILSON D. M. (2002), «Reexamining the empirical evidence for an environmental Kuznets curve», Review of Economics and Statistics, 84(3), 541551.

HEGRE H., ELLINGSEN T., GATES S., GLEDISH N.P. (2001), «Towards a democratic civil peace? Democracy, political change, and civil war, 1816-1992», American Political Science Review, 95, 33-48.

HUGON P. (2009), « Le rôle des ressources naturelles dans les conflits armés africains », Hérodote, 134(3).

JUDSON R., ORPHANIDES A. (1999), «Inflation, volatility and growth», International Finance, 2(1), 117-138.

KAPLAN S. (2008), Fixing Fragile States: A New Paradigm for Development, Praeger Security International.

LA H. A., XU Y. (2017), «Remittances, Social Security, and the Crowding-Out Effect: Evidence from Vietnam», Journal of Asian Economics

http://dx.doi.org/10.1016/j.asieco.2017.02.002

LASIDA E. (2014), «Revisiter l'institution à partir de la fragilité ». S.E.R. | «Études » 2014/12 


\section{International Journal of Social Science and Economic Research}

ISSN: $2455-8834$

Volume:06, Issue:07 "July 2021"

décembre | pages 41 à 52, ISSN 0014-1941.

LIU K., BOQIANG L. (2019), " Research on influencing factors of environmental pollution in China: A spatial econometric analysis», Journal of Cleaner Production, 206, 356-364.

MACEDO D. R., HUGHES R.M., KAUFMANN P.R., CALISTO M. (2018), « Development and validation of an environmental fragility index (EFI) for neotropical savannah biome», Science of the Total Environment, 635, 1267-1279.

MCKAY A., THORBECKE E. (2019), « The Anatomy of Fragile States in Sub-Saharan Africa: Understanding The Interrelationship Between Fragility and Indicators of Wellbeing». Review of Development Economics, 23(3), 1073-1100.

MINSKY H.P. (1992), « The financial instability hypothesis », The Levy Economics Institute Working Paper Collection, ${ }^{\circ}$ WP74.

NAY O. (2013), « La théorie des États fragiles : un nouveau développementalisme politique ? » Gouvernement et action publique, 2, 139-151.

NEWMAN E. (2009), «Failed states and international order: constructing a post-Westphalian world». Contemporary security policy, 30, 3, 421-443.

NORTH D.C. (2005), Understanding the Process of Economic Change, Princeton University Press, traduction française, (2005), Le processus du développement économique, Paris, Éditions d'Organisation.

NORTH D.C. (1990), Institutions, institutional change, and economic performance. Cambridge University Press, Cambridge.

OCDE (2017), États de fragilité 2016 : Comprendre la violence, Éditions OCDE, Paris, pp. 204.

ONGO NKOA B.E. (2019), «Effets différenciés des IDE sur la croissance économique africaine : le rôle de la finance », Revue d'Economie de Développement, 26(3), 33-63.

ONGO NKOA B.E., SONG J.S. (2018), « La qualité des institutions réduit-elle la volatilité des investissements directs étrangers en Afrique ?», Mondes en développement, 183(3), 113-131.

ÖZERDEM A., PODDER S. (2011), "Disarming youth combatants: Mitigating youth radicalization and violent extremism”. Journal of Strategic Security, 4(4), 63-80.

RENO W. (2011), Warfare in Independent Africa, Cambridge University Press, Cambridge. 


\section{International Journal of Social Science and Economic Research}

ISSN: $2455-8834$

Volume:06, Issue:07 "July 2021"

REYNAL-QUEROL M. (2005), «Does democracy preempt civil wars? ». European Journalof Political Economy, 21, 445- 465.

REYNAL-QUEROL M. (2002a), «Ethnicity, political systems, and civil wars». Journal of Conflict Resolution 46, 29-54.

REYNAL-QUEROL M. (2002b), «Political systems, stability and civil wars». Defense and Peace Economics 13, 465-483.

RIVERA M. (2016), «The sources of social violence in Latin America: An empirical analysisof homicide rates, 1980-2010». Journal of Peace Research, 53(1).

ROBERTS J.T. et Parks B. C. (2007). A climate of injustice: Global inequality, north-south politics, and climate policy. Cambridge (MA): MIT Press.

RODRIK D. (1999), «Democracies pay higher wages». Quarterly Journal of Economics, 114(3), 707-738.

ROMUALD K.S. (2011). Democratic institutions and environmental quality: effects and transmission channels. In 2011 International congress, August 30-September 2, 2011, Zurich, Switzerland (No. 120396). European Association of Agricultural Economists.

SAMBANIS N. (2001), «Do ethnic and nonethnic civil wars have the same causes? Atheoretical and empirical enquiry (part 1)», Journal of Conflict Resolution, 45, 259-282.

SCHUMPETER J. (1942), Capitalism, Socialism and Democracy. New York: Harper Brothers.

SCRUGGS L.A. (1998), «Political and economic inequality and the environment», Ecological Economics, 26(3), 259-275.

SINAPI C., PIEGAY P., DESMEDT L. (2010), « L'analyse des crises : MINSKY, aprèsFISHER et KEYNES », L'Économie politique, 48(4), 85-104.

SOBEK D. (2010), «Masters of their domains: The role of state capacity in civil wars ». Journalof Peace Research, 47(3).

STEWART, F. et G. BROWN, (2009), Fragile States, Working Paper No. 51. Oxford: Centrefor Research on Inequality, Human Security and Ethnicity.

TENDETNIK C., CLAYTON C., CATHCART K. (2018), «Education and nation-state fragility: Evidence from panel data analysis». International Journal of Educational Development, 62, 17- 
26.

THEISEN O.M., NILS P.G., HALVARD B. (2013), «Is climate change a driver of armed conflict? », Climatic Change, 117, 613-625.

TODARO M. P. (1969), «A Model of Labor Migration and Urban Unemployment in Less developed countries», American Economic Review, 59(1), 138-148.

TORRAS M., BOYCE J.K. (1998), «Income, inequality, and pollution: a reassessment of the environmental Kuznets curve». Ecological Economics, 25, 147-160.

VALLINGS C., MORENO-TORRES M. (2005), Drivers of fragility: What mak es states fragile? PRDE working paper no. 7 (http: // webarch ive.nationalarchives.gov.uk/-f/ http: // www. Dfid.gov.uk/ documents / publications / fragile- states / drivers-fragility.pdf).

WAN-HAI Y., HUI-MING Z., KEMING Y., CHENG P. (2014), «Democracy, Financial

Openness, and Global Carbon Dioxide Emissions: Heterogeneity Across Existing Emission Levels». World Development, 66, 189-207.

WILLIAMSON O. (2001), «The New Institutional Economics: Taking Stock/looking ahead». Journal of Economic Literature, 37, 595-613. 